\title{
Overview of interport competition: Issues and methods
}

\author{
Young-Tae Chang and Paul T.W. Lee*
}

\begin{abstract}
Port competition attracted much scholarly attention in Northwest Europe during the 1980s. Following the rise of powerful economies in East Asia, particularly during the 1980s and 1990s, port competition has become an important phenomenon with the top five container ports in the world being located in the region. This paper aims to overview major port competition issues and outlines and analyzes the main alternative methodologies that researchers have employed to address them, referring to 70 items, mostly papers but including a few books and reports
\end{abstract}

Keywords: port competition, privatization, productivity and efficiency, port selection, methodology.

\section{Introduction}

Traditionally, interport competition was regarded as being of minor concern before the era of containerization. ${ }^{1}$ Port markets used to be perceived as being monopolistic or oligopolistic, because of the exclusive and immovable geographical location of the port and the unavoidable concentration of port traffic that this engendered (Cullinane et al., 2005).

The container revolution commenced during the late 1950s in the USA. Then ensuing two decades of international trade boom in the world led to the development of modern container ports, particularly in Western Europe and North America. With the advent of full-fledged containerization, interport competition has been a long-standing issue in the maritime research arena. This emphasis is likely to continue given the need to incorporate the supply chain management principles and value-driven approaches that contemporary ports need to address to

\footnotetext{
Submission Date:28/11/2005 Acceptance Date: 30/5/2007

*Professor, Asia Pacific School of Logistics (APSL), Inha University, email: ytchang@inha.ac.kr and Professor, Department of Logistics and Shipping Management, Kainan University, Taiwan, email: paultwlee@mail.knu.edu.tw, respectively.

${ }^{1}$ Interport competition or port competition are used interchangeably.
} 
enhance their competitiveness. (Robinson, 2002; Bichou and Gray, 2004)

Port competition attracted much scholarly attention in Northwest Europe during the 1980s, where traditionally strong container ports in the 'North Range', notably Hamburg, Bremen, Rotterdam, Antwerp, Felixstowe and Le Havre, competed aggressively against each other (PetezLabajos and Blanco, 2004; Pallis and Vaggelas, 2005). Following the rise of powerful economies in East Asia, particularly during the 1980s and 1990s, port competition has become an important phenomenon with the top five container ports in the world being located in the region. Since the 1990s Hong Kong and Singapore have been two dominant container ports until their suzerainty was challenged at the beginning of the twenty-first century by China's ports of Shanghai and Shenzen, which had already surpassed the world's former third-ranking port of Busan and the port of Kaohsiung in Taiwan. Numerous Japanese container ports have left the top echelons of the world container port rankings; Kobe disappeared from the lists after the 1996 earthquake (Chang, 2000). China, Korea, Japan and Taiwan have all invested heavily in port infrastructure to develop regional superhubs (Wang and Slack, 2004; Yap and Lam, 2006). Modern, container-based port competition that was initiated in Europe is now at its peak in East Asia and can be observed in other parts of the world including North America (Ircha, 2001) and even, to some extent, Africa (Hoyle and Charlier, 1995). Today's competing ports are facing another challenge arising from a new logistics paradigm in which ports have to recast themselves as an integral element of the supply chain (Robinson 2002). In sum, port competition seems pervasive in the world and contemporary ports are not solely competing between ports, but between supply chains where the relevant ports belong.

In this context, this paper overviews major port competition issues and outlines and analyzes the main alternative methodologies that researchers have employed to address them. To this end, we have surveyed the major transportation journals and maritime logistics fields. Section 2 categorizes and describes major port competition issues and section 3 analyzes the methodologies. Conclusions are drawn, before possible future research agendas are suggested.

\section{Issues of interport competition}

Over the years, researchers have focused on different aspects of port competition. Their major concerns have been:

(1) how inter-port competition is affected by different governance structure, ownership and privatization;

(2) how can inter-port performance be measured, particularly in terms of productivity and efficiency;

(3) how can ports compete and cooperate;

(4) what competitive policies can be formulated and implemented; and

(5) what factors are important in port choice decisions? 
Figure 1 shows the classification of the issues and relevant papers that we found in the literature. This section discusses these issues.

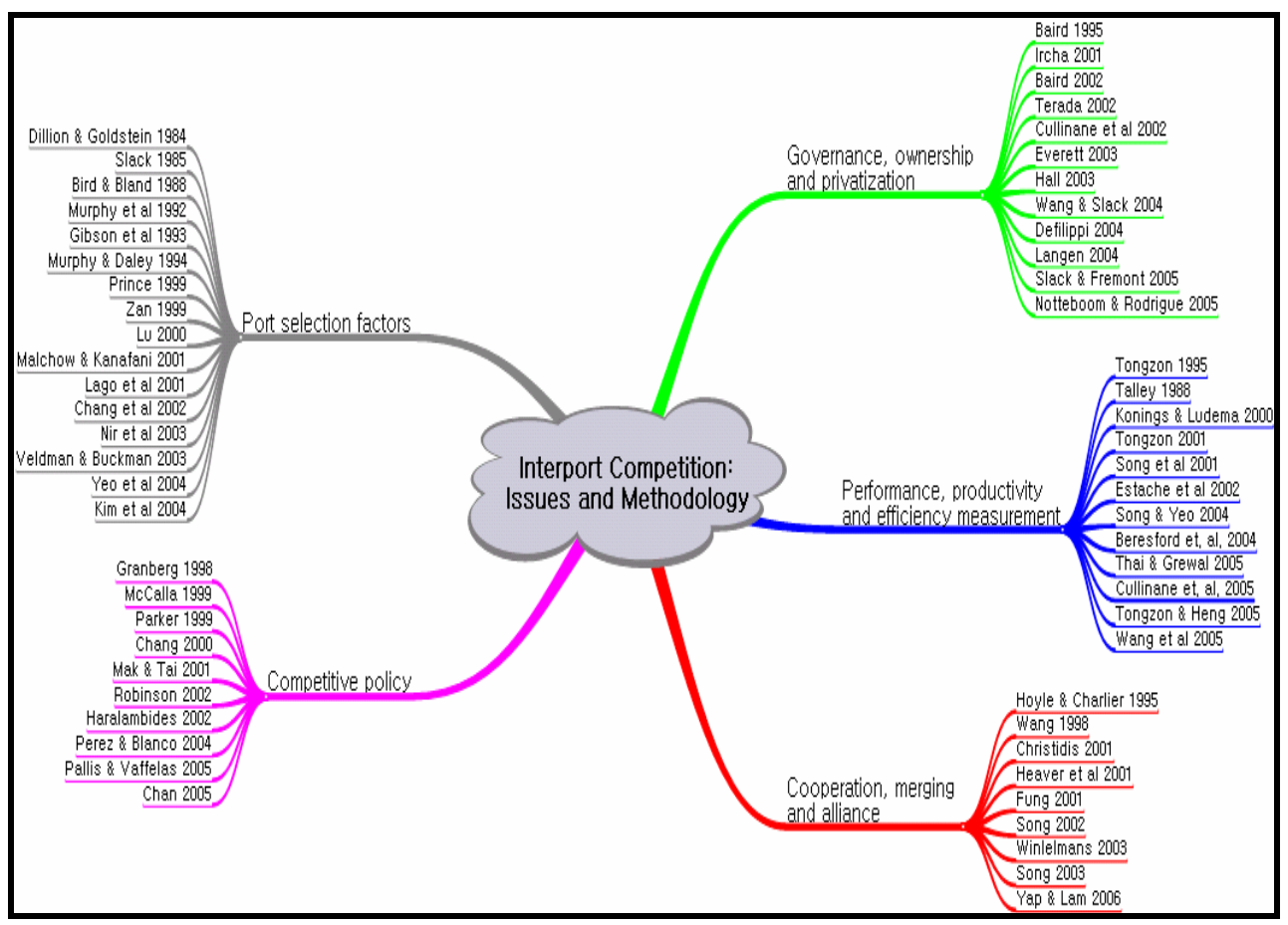

Fig. 1. Interport competition: Issues and methodology

\subsection{Governance, ownership and privatization}

Researchers have been interested in finding how the governance structure of ports affects their competitiveness. A growing number of ports have adopted privatization assuming that the process will lead to more efficiency and lower costs, thereby enhancing port competitiveness. (Everett, 2003).

Baird (2002) was interested in assessing this research question by examining the world's top100 container ports. Specifically, he attempted to address the following issues:

- What is the extent of private sector intervention in seaports;

- Which specific seaport activities do the public and private sector perform;

- What methods of privatization are used; and

- What are perceived to be the main advantages and disadvantages of these changing institutional arrangements? 
In addition, Everett (2003) questioned why, after five years' implementation, the restructuring of Australian ports into corporatized entities still resulted in suboptimal performance. She suggested that the root cause of port inefficiency - political interference - is, in fact, the effect of a legislative framework which has created an organizational structure that demands ongoing ministerial intervention.

Bird's (1963, 1971) 'Anyport' model, outlining a three-stage port development process setting, expansion and specialization - is limited in explaining contemporary container port development, particularly in two aspects of development: (1) the recent rise of seaport terminals that primarily act as transshipment hubs in extensive maritime hub-and-spoke and collection and distribution network (e.g., offshore or island locations with limited or no local hinterland); and (2) inland dimension as a driving factor in port development dynamics. To explain this gap, Notteboom and Rodrigue (2005) introduced regionalization as a new phase to the traditional port development model. It had been developed by Rimmer (1967) from the Taafee, Morrill and Gould model (1963) which had been focused on land developments in underdeveloped countries.

Privatization of trust ports in the United Kingdom (UK) was analyzed using five sales under the Ports Act 1991. The sales were completed in 1992 and one of the issues addressed was whether privatization contributed to port competition or not (Baird, 1995).

Cullinane and others (2002) assessed the influence of administrative and ownership structure using a stochastic frontier model of the efficiency of major container terminals in Asia. The authors tried to assess the relative efficiency between publicly and privately-owned ports based on 'port function matrix' suggested by Baird (1995) using an econometric technique known as the stochastic frontier model.

Wang (1998) attempted to understand and interpret the dramatic changes in the Pearl River Delta (PRD) and Hong Kong. On the basis of this initial research, Wang and Slack (2000) identified four causes of; (1) the downgrading of Hong Kong from a transshipment hub port for Greater China to a regional load center; and (b) the emergence of deep-sea direct service ports in PRD. The causes stemmed from the impact of: the cost-based competition, the unique 'onecountry two-systems' policy, globalization through container standardization, and multi-modal accessibility and connectivity.

Wang and others (2004) addressed recent institutional changes in China's port industry in relation to an ongoing internationalization of port management, paying special attention to the role of port authorities and specific corporatization practices under reform. In so doing, Shanghai and Shenzen ports were used as case studies. He analyzed the port governance of the two ports and scalar politics in China from the national to the local. He concluded that the governance approach applied in his research explains the interrelationship between China's port stakeholder communities, logistical capabilities as well as scalar politics through institutional factors.

Defilippi (2004) analyzed which concession alternative for the state-owned Callao port mono- or multi-operator - was more beneficial for Peruvian society. His paper is concerned with intra-port competition, which depends upon both the port's regulatory options and the extent of government intervention by subsidy.

Slack and Frémont (2005) differentiated between two types of terminal operation, transnational terminal operating companies and shipping lines, in terms of governance, competition, 
and capacity, and explored the question of why the distinctions between terminal operations should be regionally based by examining the variations between the USA and Europe with specific reference to France.

De Langen (2004) identified the seaport clusters through a literature survey and analyzed how they affected the governance of port authorities, making comparisons between Rotterdam, Antwerp, and Hamburg in terms of port competitiveness. The four seaport cluster factors enumerated in the paper are: trust, the presence of leader firms, solutions for collective action problems, and the presence of intermediaries.

Hall (2003) explored how the regional institutional convergence in association with the process of containerization influenced port competitiveness, taking the case of the USA Port of Baltimore. Ircha (2001) elaborated the list of strategic issues facing Canadian seaports from a brief review of the country's port reforms and an analysis of external and internal port environments. He showed how the Canada Marine Act affected strategic issues.

Terada (2002) addressed why local port authorities in Japan have been constructing and investing in container ports and other new port facilities that will certainly lead to serious financial problems and trouble local government budgets.

\subsection{Performance, productivity and efficiency measurement}

The performance evaluation of ports has used representative indicators to show port competitiveness. Research has been centered upon measuring the performance of both productivity and efficiency. Definitions and methodologies have varied depending upon researchers and over time.

Cullinane and others (2005) have evaluated the efficiency of the world's most important container ports and terminals using the two alternative techniques of Data Envelopment Analysis and the Free Disposal Hull model.

Tongzon and Heng (2005) have investigated the quantitative relationship between port ownership structure and port efficiency. They attempted to examine whether privatization is a necessary strategy for ports to gain a competitive advantage. Fifty container terminals located in Asian ports were selected to carry out the empirical study using questionnaires. Port ownership structure was discussed using Baird's (1995) port function matrix.

Tongzon (1995) aimed to specify and empirically test the various factors that influence port performance and efficiency. He sent questionnaires requesting 1991 data on port performance and efficiency to 30 container ports based on size, geographical location and data availability. Twentythree sampled ports responded. With this data Tongzon (2001) examined efficiency with respect to containerized cargoes across ports recognized for their high level performance in Asia and Europe for which data are available. He used two output and six input measures of port performance for the year 1996. The two output variables were cargo throughput (TEUs) and ship working rate (container moves per working hour per ship). The six input variables were number of berths, cranes, tugs, number of port authority employees as a proxy for stevedoring labor, terminal area and delay time.

Estache and others (2002) illustrated how measures of relative efficiency performance could 
promote competition between port infrastructure operators, using the Mexican 1993 Port Reform as a case study. They drew three main conclusions: first, that the Mexican port reform generated 2.8-3.3\% of the average annual growth rate in the port efficiency; secondly, that the assessment of the port-specific efficiency gains achieved is was also important for any regulator mandated to pass on the gains from reform to the port users; and finally, that the analytical sound performance rankings allowed by these port-specific efficiency measures assisted in promoting competition within the sector.

Thai and Grewal (2005) identified some problems caused by outdated work practices, low efficiency and poor competitiveness of the current Vietnamese port system and proposed development strategies to tackle them. The catalogue of issues include: (1) division of responsibility among the various governing bodies under different government ministries; (2) complicated role of port authority comprising a state, municipal, public or private bodies, which is responsible for construction, administration, and sometimes the operation of port facilities and, for security; (3) various port models; the differential pricing policy under various governmental bodies and as a consequence, (4) the differential service tariff for local and foreign investment enterprise; and (5) low productivity with poor IT and EDI application.

Song and Yeo (2004) investigated empirically the competitiveness of container ports in China using the Analytic Hierarchy Process (AHP), under which elements and factors influencing competitiveness were identified. Hong Kong, Shanghai, Yantian, Qingdao, Tianjin, Xiamen, Dalian and Shekou, ranking among the world's top 50 container ports, were included.

Generally, the performance of marine terminals has been evaluated by comparing actual with optimum throughputs. To calculate the optimum throughputs, engineering and economic approaches are usually employed (Talley, 1988).

After carrying out a critical review of the UNCTAD Three Generation Port Model proposed in 1992, Beresford and others (2004) suggested that it should be replaced by the 'Work Organization in Ports' (WORKPORT) model derived from a two-year research project (19981999) funded by the European Commission. The UNCTAD model not only provides an unrealistic and inaccurate description of the port industry on a global scale but also does not reflect the situation which has prevailed since the 1960s in terms of ownership, cargo forms, cargo handling process, cargo support systems and information provision, working culture, port function and development, health and safety, environment, and decision factors. Conversely, the WORKPORT model incorporates all of these key factors in port development.

\subsection{Cooperation, merging and alliance}

Heaver and others (2001) addressed the issue of cooperation and competition among ports in discussing how port authorities respond to their changing market environment. The authors document the changes taking place in the relationships between port authorities and terminal management companies and consider the strategic issues faced by these groups and other port interests. Various international cases, involving mergers and alliances, are exemplified to highlight these new forms of cooperation between ports. Cases include the merger between the ports of Copenhagen, Denmark and Malmo, Sweden, enabled by the Oresund Fixed Link; cooperation 
agreements between Rotterdam and Flushing with regard to joint investment, and among the ports of Antwerp, Ghent Terneuzen and Flushing for more structural coordination; collective general marketing and lobbying on matters of mutual interests by the Northwest Terminal Operators Association in the US; merging between stevedoring companies between Hessennatie and Noordnatie in Antwerp to attain a stronger negotiation position vis-à-vis shipping companies and the port authority; and the development of international networks by major terminal operating companies such as P\&O Ports, Hutchinson Port Holdings and Port of Singapore Authority.

Song (2002) examined possible competition and co-operation between adjacent container ports in Hong Kong and South China from a strategic perspective, after reviewing their current and prospective status. He argued that the current share structures operators and ownership pattern of terminals within Hong Kong port and Shenzhen port may affect either competition or co-operation. Employing the concepts of co-opetition (combining competition and cooperation), derived from Brandenburger and Nalebuff (1966), market power theory and joint venture, Song (2002) suggested that co-opetition and co-opetitive alliances are useful for explaining relations between Hong Kong and Shenzhen ports. Song (2003) also uses co-opetition to explain relationships between the container ports in Hong Kong and South China.

Fung (2001) attempted to provide a systematic treatment of the interactions between the ports of Singapore and Hong Kong and to investigate how the rise of South China ports affects the demand for Hong Kong container handling services. This study focused on capturing both the long-run equilibrium and the short-run dynamic of the interaction between the Hong Kong terminals, the Hong Kong midstream and Singapore terminals. The long-term equilibrium refers to the equilibrium that the system is asymptotically converging to, while the short-run dynamic refers to the short-run interactive relationship that arises from the trade-interdependency and oligopolistic relationship. This study was undertaken to assess the need for new container terminals in Hong Kong by projecting future demand, while presupposing that each level of demand is met with operational efficiency.

Yap and Lam (2006) examined the competitive dynamics between the major container ports in East Asia by analyzing their extent and intensity using time series data between 1970 and 2001 . They used data on container throughput for the container ports of Hong Kong, Kaohsiung, Keelung, Kobe, Nagoya, Osaka, Busan, Taichung, Tokyo and Yokohama, sourced from yearbooks and magazines published by Containerization International.

Hoyle and Charlier (1995) attempted to survey inter-port competition in developing countries, using an East African case study. Their findings are, first that port concentration is an outcome of investment in port facilities and in related transport infrastructures; secondly, that the competitive position of a port is a critical to its commercial survival; and, thirdly, that there is a substantial degree of continuity between past and present situations involving the factors, processes and interrelationships reviewed.

Christidis (2001) argued that technological developments in the transport industry and the globalization of competition are transforming the environment in which ports operate and, in response, transport and port operating companies are forming alliances to operate more efficiently. He also maintained that the leading ports in Europe are increasingly logistics providers rather than simply port operators. Thus, they are both horizontally to form larger groups or networks of ports 
and vertically with other parts of the transport chain.

Van Klink and van den Berg (1998) elaborated the hypothesis that gateways are excellently positioned to stimulate intermodal transport in Europe and use this system as a tool to enlarge their hinterlands. They were tested for the relationship between Rotterdam, one of Europe's gateways, and Italy that lacks a central container port. The hypothesis was accepted in that in the case of Rotterdam, intermodal transport can extend the port's hinterland, and the introduction of shuttle trains to Italy, supported by the Rotterdam Port Authority, has added to the transshipment of containers to/from Italy in Rotterdam. Stimulating intermodalism from gateways is a means for seaports to keep their share in the changing European market and to enlarge their hinterland towards new regions, thereby improving the efficiency of the transport system.

Wang (1998) examined the development of Hong Kong container port in the light of the Hayuth's five-stage load center model. He identified that the validity of the Hayuth's model was not confirmed in the context of Hong Kong and South China because the former's hinterland exists in a different economic system and at a different development level. Consequently, Wang argued that Hong Kong and Yantian will act together as a twin port load center to serve the integrating South China-Hong Kong region, with the latter being run by operators from the former. As a result, he expected more collaboration between the two ports to achieve a win-win situation. As noted, Wang's analogy and conclusion were elaborated by Song $(2002,2003)$ using co-opetition market power theory and joint venture.

\subsection{Competitive policy}

Robinson (2002) suggests a new paradigm for examining port competitiveness in a changing environment. The new logistics-restructured environment requires us to look at ports as a segment of a whole supply chain rather than the port per se and therefore a new strategy and perspectives are needed. He suggests a new conceptual framework that incorporates the port as an element in valuedriven chain systems.

Haralambides (2002) addresses the issue of the 'right' pricing system for ports, arguing that right prices an lead a port to prosperity and growth and wrong ones can guide it to extinction or to the proliferation of subsidies and inefficiency. With references to the EU's policy direction on ports, he explains how ports in neighboring areas are competing and how costs should be recovered, and how pricing mechanism can affect a port's short run and long term economic viability under various competing scenarios.

After reflecting on changes in commercial and technological factors in the commercial sea, loss of client loyalty and the appearance of new operating rules, Perez-Labajos and Blanco (2004) addressed the controversies of the EC Commission's new legislative framework. This paper identified commercial and technological policies for formulating strategies to improve port competitiveness. In this context, ports will have to try to connect the logistics platforms or act as hub centers. In addition, they must also win client loyalty in a context of co-operation. Recognizing the need to match the gradual adaptation of the legislative framework on port activity to the current requirements of self-sufficiency and increasing international competitiveness, ports must not only implement their investment correctly but also manage their resource efficiently. 
Pallis and Vaggelas (2005) attempted to identify whether or not port competitiveness of Greek ports would exist when a 'port services' directive proposed by the European Commission in 2001 was implemented in Greece.

The research report by Charles River Associates Ltd. (2002) that was intended to provide the Government of New Zealand, among others, with an overview of the competition issues facing shipping ports presented a qualitative evaluation of the extent of any market power and the efficiency consequences in the country's industry by: (1) identifying and analyzing the characteristics of the ports market(s); (2) assessing factors influencing market power in the ports market(s), including the constraints imposed by existing institutional and regulatory measures; and (3) providing an overview of port markets with specific description of the pattern and frequency of market power occurrences and implications for efficiency.

Chan (2005) studied the interaction between interstate and intrastate regulations before and after the passing of the Motor Carrier Act and the Staggers Act of 1980, using as case study of the transport of dried beans.

Focusing on Port Kelang to make it a regional hub port against Singapore, Mak and Tai (2001) argued that national transport policy and port policy should be incorporated into an integrated transport policy. They maintained that the purpose of national port policy is to: facilitate trade; empower Malaysian ports; make Port Kelang the national load center and regional hub; and ensure that all Malaysian trade goes through Malaysian ports and save foreign exchange. These arguments are rooted in protectionism cast in terms of government intervention and infant industry.

McCalla (1999) focused on local adjustments that ports are making to accommodate globalization trends through an examination of terminal constructions or expansion and addition of post-Panamax cranes in the ports of Halifax and Vancouver. He concluded that the impact of intermodality occurs at both global and local levels and that ports must respond to the former. The case shows that Vancouver could construct a modern terminal with the cooperation of the port, ocean operators and railroads, while Halifax has not been able to follow suit.

\subsection{Port selection factors}

Previous studies of port choice models have differed over time, along trade routes, cargo, methodologies, sampled data and surveyed subjects. The majority of the studies, however, centered on the port choice model involving decisions by shippers rather than by other stakeholders.

Slack (1985) examined the factors considered by exporters and freight forwarders in containerized traffic between the North American Mid-West and Western Europe. Gibson and others (1993) also surveyed shippers to check their strategy in purchasing transportation services. Further, Murphy and Daley (1994) surveyed US purchasing managers to discover how they selected international water ports. Nir and others (2003) analyzed shippers' port choice behavior in Taiwan using a multinomial logit model. Yeo and others (2004) surveyed export and import companies using small and medium ports in Korea. Research was conducted by Bird and Bland (1988) on freight forwarders using 72 interviews from 11 European countries.

Malchow and Kanafani (2001) examined what factors affected the port selection of US cargo liners. They used four factors such as oceanic distance, land distance, frequency of ship sailings and 
vessel capacity by employing a multinomial logit model. Simultaneously, Lago and others (2001) examined the routes of vessels along the U.S. West Coast between 1993 and 1999. Further, Kim and others (2004) differentiated external factors from internal factors germane to the major port arena and sought to check if these factors changed over time.

Murphy and others (1992) attempted to learn if there were differences in port selection factors among the five groups of ports, carriers, freight forwarders, large US shippers and smaller US shippers. Zan (1999) built a game theoretical model to explain the interaction between port, carriers and shippers. Lu (2000) examined logistics services and strategic dimensions in Taiwanese shipping companies, agencies and freight forwarders.

Veldman and Buckman (2003) were approached to set up a model to explain the market share of a port's routings for each of the traffic zones or regions covering a port's potential hinterland in Western Europe. This model is regarded as a useful tool for the assessment of container port market shares in situations where competing ports have large overlapping hinterlands.

\section{Methodologies used in port competition research}

\subsection{Governance, ownership and privatization}

Baird (1995) used case studies of the first five ports sold in the U.K. and analyzed the effect of privatization on port competition, mostly based on descriptive nature of port competition between the pre-privatization and post-privatization periods. His findings were that, in spite of the most pure privatization in the world, the U.K. cases resulted in the creation of private estuarial monopolies, entirely defeating the governments stated objective of increasing competition in the ports industry. Baird (1995, 2002) used survey techniques in assessing the privatization trends at the world's top100 container ports. He sent a survey form of one page to the one hundred container ports and received 48 responses. His survey shows that vast majority container ports (90\%) are still owned by public sector and only $4 \%$ owned by private companies. The stated prime aim of privatization was improved efficiency and lower port costs. Terminal concession or lease was the most common method of privatization.

Everett (2003) did not use any empirical analysis on testing her research questions, but drew her conclusions from both the literature and very descriptive reasoning. She argued that the current legislative framework in Australia prevents ports from creating an independent business model since Ministers are obliged to determine strategic directions. Consequently, port authorities are driven by short-term political needs satisfying the demands of the electorate rather than the commercial objectives imposed on port corporation.

Notteboom and Rodrigue (2005) used a conceptual model in explaining their port development model. They argued that inland distribution becomes of foremost importance in port competition, favoring the emergence of transport corridors and logistics poles. Port authorities can play an important role through an active engagement in the development of inland freight distribution, information systems and intermodality. 
Cullinane and others (2002) used a stochastic frontier model to consider a linear model for the frontier production function as follows:

$$
Y_{i t}=f\left(X_{i t} ; \beta\right) \exp \left(v_{i t}-u_{i t}\right), \quad i=1,2, \ldots, N, \quad t=1,2, \ldots, T,
$$

where, $Y_{i t}$ denotes the output for the ith firm at time $t, X_{i t}$ is a vector for inputs associated with the $i$ th firm at time $t$ and $\beta$ is a vector of input coefficients for the associated independent variables in the production function. In the disturbance term, the component $v_{i t}$ represents a symmetric disturbance term and the other component $u_{i t}$ is a one-sided disturbance term, measuring productive inefficiency. The next equation captures firm-specific time-invariant variables omitted from the previous function arising from the absence of the subscript $t$.

The productive efficiency of the $i$ th firm (PE) is defined as in equation (2).

$$
\mathrm{PE}_{i}=\frac{E\left(Y_{i t}^{*} \mid u_{i}, X_{i t}\right)}{E\left(Y_{i t}^{*} \mid u_{i}=X_{i t}\right)}
$$

Using container throughput in TEUs for output and terminal quay length in meters, terminal area in hectares and the number of pieces of cargo handling equipment for input variables, they estimated the efficiency of 15 container terminals/ports in Asia. They found that Kaohsiung, Busan and Singapore were the most efficient terminals with the cross-sectional model and Singapore, Busan and Kobe were the most efficient with the panel model, whereas Chinese ports were the most inefficient together with Manila port in both instances. Despite the emphasis in the title upon assessing the efficiency of container terminals influenced by administrative and ownership structures, they did not show empirical evidence about the linkage between the efficiency and the ownership, but purely drew conclusions contingent upon subjective and ambiguous arguments.

Wang and Slack (2000) highlighted the diversified and often conflicting local interests, regulations, and operational mechanisms that shape spatial relationships against the backdrop of global forces and organizations. Their study confirmed that the interdependencies and competitive relations between the Shenzen Ports (Yantian and Shekou) and Hong Kong are being resolved at a regional level.

Wang (1998) applied a staged model, which is a modification of Hayuth (1978) of load centers in US container ports. Compared with Hayuth's model, Wang's model is considered applicable to the container port system in any part of the world on the ground that the uniqueness of the evolution process in the container port system in South China lies in three aspects (Wang 1998):

- Containerization did not take place at the same time and within the same economy for Mainland China and Hong Kong

- Mainland ports came into direct competition with Hong Kong and faced a number of disadvantages.

Since the container port business requires intensive capital and technology with high quality of 
management, China has been forced in the short run to at least introduce foreign port operators, largely from Hong Kong, to meet the demanding requirements of international shipping lines.

Wang and others (2004) attempted to provide an adaptable framework of port governance in addressing port developments proper to China, employing the governance approach. The approach was applied to two ports, Shanghai and Shenzen ports and highlighted that it could address recent institutional changes in the China's port industry under reform.

Defilippi (2004) used regulation theory to analyze the rationale behind the two choice options of operator alternatives, both mono- or multi-operator, and Monte Carlo simulation and real-option theory to analyze the viability of the concession under both alternatives. One of the explicit limitations inherent in the valuation model was about assumptions of discount rates without any logical explanation of why they were employed. Such a shortcoming may result in biased results. In arguing pro-competitive government intervention using a subsidy, the paper has not considered its negative effects to the Peruvian national welfare. The findings of the paper are that the concession of Callao port under a mono-operator would be a better alternative, generating proceeds in excess of US\$60 million with port users expecting to pay 22\% lower tariffs for the use of the infrastructure and the subsidy would be justified under any alternatives.

Slack and Fremont (2005) used a descriptive approach showing that differences in port terminal management systems are regionally based: Transport Terminal Operators (TTOs) such as $\mathrm{HPH}$, PSA, Eurogate with horizontal integration prevails in Europe; and shipping lines with vertical integration dominate in the USA. The latter is attributable to the absence of port reform or liberalization, intense competition with neighboring ports, and the container cargo volume handled by the major carriers on the trans-Pacific trade. The TTO's, on the other hand, has a dominant position because of their ownership of terminal, high levels of expertise, promises of efficiencies, and perceived lower berth throughputs. The above developments generate the growing concentration of ownership in the terminal management sector.

De Langen (2004) used an analytical framework for seaport clusters derived from a broad literature survey. On the basis of that, an empirical case study approach was employed in association with semi-structured interviews with 43 port experts. They were selected on the basis of three criteria: job position, years of experience in the port industry and involvement in cluster governance. Evaluations by experts were scored ranging from -5 for very bad to +5 for very good. He concluded that the empirical results validated the relevance and quality of the cluster governance approach between the three competing ports. Antwerp was deemed to have better governance than both Rotterdam and Hamburg.

Hall (2003) used both descriptive and documentary approaches. He confirmed the existence of the notion of institutional transformation through a case study of the Port of Baltimore and concluded that, unlike its USA counterparts, the major port did not take regional institutional convergence seriously enough to acquire international competitive edge. The processes of institutional convergence at the Port of Baltimore failed to create an environment that cultivated competitive components. Further, the author noted public port officials were influential in shaping the process of institutional change.

Ircha (2001) used SWOT analysis method to develop port strategy for reforming Canadian ports, addressing decision and change processes, environmental scanning, organizational goals, 
resistance to change, and restructuring organizations. But the method was too weak to validate the arguments and to review the country's port reforms and an analysis of external and internal port environments, because it did not show how components of SWOT were drawn.

Terada (2002) analyzed financial statements for combined eight major ports in Japan and found that port managers' improper accounting information system about the costs and revenues of port business, and insufficient disclosure of financial statements of port business to port users and taxpayers systematically led to the overcapacity problem. He focused on institutional aspects of the overcapacity problems from the viewpoints of accounting cost and opportunity cost.

\subsection{Performance, productivity and efficiency measurement}

Cullinane and others (2005) argue that Data Envelopment Analysis (DEA) and Free Disposal $\mathrm{Hull}$ (FDH) are two of the many available alternative techniques (categorized either as economic or as mathematical programming) for estimating an approximation to the efficient frontier. DEA and FDH, as two deterministic non-parametric methods, assume no particular functional form for the boundary and ignore measurement effort. Instead, the best practice technology is the boundary of a reconstructed production possibility set based upon directly enveloping the observations. The authors use the Decision Making Unit as the most fundamental level in their analysis. Container throughput at terminals was chosen as the output variable and overall length of berths, the absolute number of quayside gantry cranes, yard gantry cranes and straddle carriers were chosen as the input variables. The authors estimated terminal efficiency using the DEA-CCR (constant returns to scale assumption), DEA-BCC (variable returns to scale assumption) and FDH methods and found some world-renowned container terminals, such as Modern Terminals Ltd (MTL) in Hong Kong to be currently suffering from inefficient production.

Tongzon and Heng (2005) employed the stochastic frontier function, using two forms, namely Cobb-Douglas and Translog. They defined the terminal output as measured by annual container throughput in TEUs and the input as measured by terminal quay length in meters, terminal area in hectares and the number of quay cranes used at the terminal. They also used port size and private participation as dummy variables. They found that the best extent of private participation in container ports/terminals is between the Private/public and the Private mode, implying that it is better for port authorities to limit the private sector participation within the 'landowner and operator' functions and take over the regulatory function. They argue that port authorities should introduce private finance, operation and management instead of state funds and administration while they remain in place as regulators. They also claimed that partial port privatization is a quite effective way to help port authorities to win in interport competition.

Tongzon (1995) built a regression model on throughput and efficiency, respectively. He used location, frequency of ship calls, port charges, economic activity and terminal efficiency as the independent variables for the throughput model and used container mix, work practice, crane efficiency, vessel size and cargo exchange (economies of scale) as the independent variables for the efficiency model. Two stage least squares estimation was undertaken in the analysis, with ship frequency, economic activity and terminal efficiency having statistical significance for the throughput model and container mix, delay in commencing stevedoring, crane productivity and 
vessel size and cargo exchange for the efficiency model, respectively.

Tongzon (2001) used both models of CCR ${ }^{2}$ DEA (constant returns to scale) and Additive DEA (variable returns to scale) with the sample of 16 ports. He found that Melbourne, Rotterdam, Yokohama and Osaka were inefficient and Hong Kong, Singapore, Hamburg, Keelung, Zeebrugge and Tanjung Priok were efficient on both models of CCR and Additive. In addition, this study showed the merits of DEA in identifying the sources of input and output inefficiency as well as the ports that can be used as a guide to focusing efforts at improving port performance.

After carrying out extensive and thorough literature survey on efficiency measures in the port sector, Estache and others (2002) built up the production frontier estimated to get the best possible assessment of the port sector's potential efficiency gains during 1996-99 and tested two functional forms for a stochastic production function, Cobb-Douglas and Translog. The estimates are based on the maximum likelihood method relying on the FRONTIER package 4.1. With the statistical results settled, the technical efficiency of each port in each year was assessed.

Song and Yeo (2004) employed the Analytic Hierarchy Process (AHP) model to incorporate quantitative and qualitative factors into the assessment of competitiveness. Receiving 180 responses out of 350 surveyed people by questionnaires, they extracted 73 detailed elements and/or factors affecting port competitiveness. From these factors, a group of 70 professionals working in various logistics-related areas chose the five most important criteria, namely cargo volume, port facility, port location, service level and port expenses. Following ordinary process of AHP's empirical test, they ranked Hong Kong, Shanghai and Yantian in order as the most competitive ports. In addition, they argued that location plays the most important role in affecting port competitiveness. However, what they actually measured was not port location, but the service frequency of liner operations as a proxy, a strategy that raises questions of validity.

In a regulated (non-competitive) transportation environment, where marine terminals are considered to have natural hinterlands, the engineering approach for determining the optimum throughput and thus for evaluating the performance of marine terminals may be appropriate. In a deregulated (competitive) transportation environment, the natural hinterlands of marine terminals have been dissipated and shippers are now able to select carriers and marine terminals that provide services at the lowest logistics cost rather than just at the lowest transportation cost. In the latter instance, an economic approach to the calculation of optimum throughput is warranted. The needs of future research in modeling the economic approach and empirical estimation were suggested (Talley, 1988).

Thai and Grewal (2005) used a qualitative approach. Despite the measurement of the efficiency, productivity and competitiveness of Vietnamese ports being key elements, they were not calculated in a scientific way but simply by the secondary data whose relevance is suspect.

Beresford and others (2004) employed a comparative approach by using the well documented UNCTAD and the WORKPORT models. As they mentioned, their arguments favoring the latter were largely subjective. Without recognizing the contribution of the former model in port studies, most of their arguments were concerned with advocacy of the WORKPORT.

\footnotetext{
${ }^{2}$ Standing for Charnes, Cooper and Rhodes for naming after the researchers' names.
} 


\subsection{Cooperation, merging and alliance}

Heaver and others (2001) used descriptive methods in showing how ports have cooperated and competed in international container transport. They also explained how tow charges declined in Europe after the introduction of competition into a monopoly situation.

Song (2002) described the current evolution of port that can best be understood by exploring concepts of horizontal and vertical integration and strategic alliances. It is questionable to justify his argument that co-operation between two firms through joint ventures enhances competitiveness and market power of the firm. It is also speculative to confirm that it can be applicable to the case of Hong Kong and Shenzhen ports. Song (2003) describes a conceptual model on co-opetition and illustrates it with an analysis of the ownership structure of ports in Hong Kong and South China.

Fung (2001) used a structural vector error correction model (VECM) to forecast the demand for container handling services, which are affected by the interaction and competition between Hong Kong, Singapore and South China ports. Trade interdependency was examined in the model using the concept of cointegration representing linear combinations of two or more non-stationary time series that are stationary. One notable message from Fung's findings was that the rise of South China ports is creating a real threat to Hong Kong's position as a hub port in East Asia. The VECM produced higher growth paths for Hong Kong container throughput than forecasts by the Hong Kong Port Development Board, to underline much depends on the scenario considered.

Yap and Lam (2006) examined the long-run relationship between various ports in East Asia using co-integration, and short-run inter-port dynamics using Error Correction Method, respectively, similar to the study done by Fung (2001). Their empirical findings revealed that Hong Kong and Busan have been the distinctive regional beneficiaries from inter-port competition since the mid-1970s. They argue that the concentration of services by shipping lines at the primary load centers might lead to intense competition between primary load centers and ports located in close proximity that share their hinterlands, such as Hong Kong versus Shenzhen, Busan versus Gwangyang Bay, Shanghai versus Ningbo versus Tianjin.

Hoyle and Charlier (1995) employed a historical approach illustrated by a well-documented East African case study to demonstrate the dynamic relationships linking ports, hinterlands and national economic areas. They argued that the factors of port geography and port economies, coupled with the process of port concentration and diffusion developed in previous studies, could draw the five-stage model to show how the broad pattern of inter-connection and balance between maritime trade routes, seaports, and hinterland transport routes has gradually evolved over the centuries.

Christidis (2001) suggested that the current evolution of ports can best understood by exploring the concepts of horizontal and vertical integration and strategic alliances.

Klink and van den Berg (1998) presented a theoretical discussion of the hinterland concept followed by an explanation of the potential effects of intermodalism on a port's hinterland. In association with such theoretical and conceptual approach, the hypothesis was tested by data on the distribution of imports and exports of countries in Europe, the destinations of shuttle trains from Rotterdam, and modal split between rail and road in the Rotterdam-Italy connection.

Wang (1998) used both a critical approach and a case study. In the light of Hayuth’s five-stage 
model, he developed his argument that the model was valid to explain the development of ports of Hong Kong-South China.

\subsection{Competitive policy}

Robinson (2002) proposes a conceptual framework to enhance the competitiveness of ports rather than showing any empirical studies. He argues that in a competitive environment, a number of chains will be focused on the port: and shippers will choose between chains on the basis of competitive advantage and value gained. Ports will compete not simply on the bias of operational efficiency or location, for example, but on the basis that they are embedded in chains (or supply chains) that offer shippers greater value. Chains compete, not individual ports.

Haralambides (2002) employs economic reasoning in explaining and discussing the issue of competition, excess capacity and the pricing of port infrastructure. No empirical analysis was undertaken even though he claims that marginal cost pricing of port infrastructure can be a powerful pricing discipline towards achieving cost recovery and fair competition among ports.

Perez-Labajos and Blanco (2004) used a logical and descriptive approach to study port competition.

Pallis and Vaggelas (2005) combined questionnaires to CEOs managing Greek ports and structured interviews. The directive originated from the 1997 Green Paper on seaports and maritime infrastructure aimed at establishing open access on the basis of transparency, nondiscrimination, and certain principles for charging, safeguarding public service obligations, and safety. But the European Parliament rejected the Green Paper in 2003.

In the Charles River Associates Ltd. The Report (2002) Chapter 5 deals with inter-port competition by focusing on the ability of port customers to substitute between ports. Chan (2005) formulated a multimodal logit model to calculate the share of transport modes. Disaggregate modeling was made owing to transit time and more intricate relationships among accessibility, frequency, and freight rates. The study's findings show that the state of regulation does have a significant influence on modal choice and, as a result, it hints which port can be selected for exports of agricultural products.

Mak and Tai's (2001) arguments are descriptive and normative. They were not based on objective evidence. For example, the assertion that Malaysian ports are already quite efficient was made without any data or evidence.

McCalla (1999) developed his arguments by suggesting shipping alliances and railroad mergers that ports should be transformed in facilities to meet global trends. Diagrams and data were combined to support his arguments.

\subsection{Port selection factors}

Slack (1985) found that the decision-makers were influenced more by price and service considerations of land and ocean carriers than by perceived differences in the ports of entry and exit. In his survey, he asked respondents to tick five factors out of given 11 factors that they considered important in port selection. The five factors most often chosen were: number of sailings, freight 
rates, proximity of port, congestion and intermodal link. Gibson and others (1993) found that their strategies had become based more on cooperative information-shared partnerships between shippers and carriers over the past five years. Murphy and Daley (1994) found shipment information, and loss and damage performance were the most important factors. Nir and others (2003) found that time and cost were significant. Yeo and others (2004) found that cost, inland connections, fast service and the information system were critical for the small and medium ports to attract the attentions of shippers.

Bird and Bland (1988) found that freight forwarders chose ports based on the frequency of shipping services. Time spent en route and labor problems at ports were also major concerns of the respondents. In addition, port charges and guaranteeing 'delivered price' seem to have affected the port selection. While describing the research process, Bird and Bland (1988) noted the language difficulty in making the researchers understood during the interview and also in the questionnaires due to different cultures and jargon.

Malchow and Kanafani (2001) ran the model using a nested logit structure among eight seaports. They found that the oceanic distance and inland distance affected port selection in negative way. Lago and others (2001) found that carriers tended to choose the number of ports before specifying the ports. Kim and others (2004) found that internal factors were time invariant whereas external factors were time variant.

Murphy and others (1992) found from an analysis of variance (ANOVA) test and Duncan multiple range tests that there were differences across the groups and that water ports tended to view water carriers as their primary customers. While it was possible to explain the interaction between shippers and carriers, Zan (1999) was unable to explain the interaction between port and the other parties due to lack of policy data from ports. The research results of Lu (2000) based on interviews and surveys revealed that the most important strategic dimensions of the maritime companies were value-added service, promotion, equipment, facilities, speed and reliability.

The model of Veldman and Buckman (2003) presented in their paper was used to quantify the routing choice and to derive from that a demand function, which is used for port traffic forecasting and for economic and financial evaluation of container port projects. However, the model has a strong limitation in that the cross-elasticities of demand are restricted. In order to overcome these limitations, the translog demand function tried by Oum (1989) was applied to their study. Their contribution was found in that apart from the usual variables such as costs and time differences, a quality of service variable, related to market share, was also adopted.

\section{Conclusions}

We selected 70 items, mostly papers but including a few books and reports, and thus attempted to identify major issues in port competition and what methods were applied to unravel them. The topics were classified into the five categories: (1) governance, ownership and privatization; (2) performance, productivity and efficiency measurement; (3) cooperation, merging and alliance; (4) competitive policies; and (5) port selection factors (Table 1). 
Table 1

Major issues in port competition: key authors and methodologies

\begin{tabular}{|c|c|c|c|}
\hline Issues & Authors & Methodologies & Remarks \\
\hline $\begin{array}{l}\text { Govemance, } \\
\text { ownership and } \\
\text { privatization }\end{array}$ & $\begin{array}{l}\text { Goss (1990), Baird(1995), Wang(1998), } \\
\text { Wang \& Slack(2000), Ircha(2001), } \\
\text { Baird(2002), Cullinane et al. (2002), } \\
\text { Terada(2002), Everett(2003), Hall } \\
\text { (2003), Wang et al.(2004), DeLangen } \\
\text { (2004), Notteboom \& Rodrigue(2005), } \\
\text { Slack \& Fremont(2005) }\end{array}$ & $\begin{array}{l}\text { Case studies, Surveys, } \\
\text { Descriptive reasoning, Stochastic } \\
\text { frontier model, Monte Carlo } \\
\text { simulation, Real-option theory, } \\
\text { Descriptive \& documentary } \\
\text { approach, SWOT analysis, } \\
\text { financial analysis }\end{array}$ & $\begin{array}{l}\text { Majority: descriptive, } \\
\text { survey, nomative; } \\
\text { A few empirical }\end{array}$ \\
\hline $\begin{array}{l}\text { Performance, } \\
\text { productivity and } \\
\text { efficiency } \\
\text { measurement }\end{array}$ & $\begin{array}{l}\text { Talley(1988), Tongzon(1995), Konings } \\
\text { \& Ludema(2000), Song et al.(2001), } \\
\text { Tongzon(2001), Estache et al.(2002), } \\
\text { Song \& Yeo(2004), Beresford et. al. } \\
\text { (2004), Bichou \& Gray (2004), Cullinane } \\
\text { etal(2005), Thai \& Grewal(2005), } \\
\text { Tongzon \& Heng (2005), Wang et al. } \\
\text { (2005), Thai \& Grewal (2005) }\end{array}$ & \begin{tabular}{|l|} 
Stochastic frontier, Production \\
function, Cobb-Douglas, Translog, \\
Regression, Analytic hierarchy \\
process, Qualitative comparative \\
approach, DEA, FDH, conceptual
\end{tabular} & $\begin{array}{l}\text { Majority: rigorous } \\
\text { models }\end{array}$ \\
\hline $\begin{array}{l}\text { Cooperation, } \\
\text { merging and } \\
\text { alliance }\end{array}$ & $\begin{array}{l}\text { Hoyle and Charlier(1995), Van Klink \& } \\
\text { Van Den Berg(1998), Wang(1998), } \\
\text { McCalla(1999), Heaver et al.(2001), } \\
\text { Fung(2001), Christidis(2001), Song } \\
\text { (2002), Winlelmans(2003), Song(2003), } \\
\text { Yap \& Lam(2006) }\end{array}$ & $\begin{array}{l}\text { Theoretical and conceptual } \\
\text { approach, Historical approach, } \\
\text { Case study, descriptive, Vector } \\
\text { Enor Comection Model, } \\
\text { Cointegration }\end{array}$ & $\begin{array}{l}\text { Majority: conceptual, } \\
\text { descriptive, case studies; } \\
\text { A few empirical }\end{array}$ \\
\hline $\begin{array}{l}\text { Competitive } \\
\text { policies }\end{array}$ & $\begin{array}{l}\text { McCalla (1999), Mak \& Tai (2001), } \\
\text { Charles River Associates Ltd. (2002), } \\
\text { Robinson(2002), Haralambides(2002), } \\
\text { Perez-Labajos \& Blanco(2004), Chan } \\
\text { (2005),Pallis \& Vaggelas(2005) }\end{array}$ & $\begin{array}{l}\text { Descriptive approach, } \\
\text { Questionnaire, Analysis of } \\
\text { competition components, } \\
\text { Multimodal logitmodel, } \\
\text { Disaggregatemodeling, } \\
\text { conceptual, descriptive }\end{array}$ & $\begin{array}{l}\text { Mixture of descriptive, } \\
\text { survey and empirical }\end{array}$ \\
\hline $\begin{array}{l}\text { Port selection } \\
\text { factors }\end{array}$ & $\begin{array}{l}\text { Dillion \& Goldstein(1984), Slack(1985), } \\
\text { Bird \& Bland(1988), Murphy et al. } \\
\text { (1992), Gibson et al.(1993), Murphy \& } \\
\text { Daley(1994),Zan(1999), Prince(1999), } \\
\text { Zan(1999), Lu(2000), Lago et al.(2001), } \\
\text { Malchow and Kanafani(2001 \& 2004), } \\
\text { Chang et al.(2002), Nir et al.(2003), } \\
\text { Veldman \& Buckmann (2003), Kim } \\
\text { et al.(2004), Yeo et al.(2004) }\end{array}$ & \begin{tabular}{|l|} 
Surveys, Interviews, \\
Questionnaire, Logit model, \\
ANOVA, Duncan multiple range \\
tests, Demand function, Translog \\
demand function
\end{tabular} & $\begin{array}{l}\text { Majority: survey; } \\
\text { a few demand function }\end{array}$ \\
\hline
\end{tabular}


All of the five major issues involved container ports from most of the world's regions, though, more recently, additional weight has been given to Asian ports. Although different strategies have proliferated since the 1990s, the techniques used can be conveniently distilled into quantitative, qualitative, and mixed approaches. In comprehending differences between these approaches, a researcher needs to consider three key elements: (1) philosophical assumptions about what constitutes knowledge; (2) general procedures of research or strategies of inquiry; and (3) detailed procedures of data collection, analysis, and writing or methodology.

Interestingly, rigorous mathematical and econometric models have been widely used for gauging performance, productivity and efficiency, while qualitative surveys have been employed to discuss governance, ownership and privatization, and port selection. Generally, the issue of cooperation, merging and alliance involved conceptual, descriptive and case studies.

Despite extensive research, some issues are still unresolved. The following questions warrant further investigation:

- What is a hinterland and which ports are competing?

- How will the issue of port security influence port efficiency and competitiveness?

- Is privatization effective to make ports more competitive; and

- How can differences in the relative efficiency of competing ports be measured?

Various results that have been drawn on these topics from past research are due, at least in part, to design problems. Indeed, Cullinane and others (2005) argue that the most important criteria for judging whether two container ports are competing against each other is to examine if they serve identical or overlapping hinterlands. This may be a starting point in initiating a research program to address the outstanding questions listed above. In designing the program attention needs to be paid to how contemporary hinterlands are evolving in response to the changing environment stemming from the restructuring of the value-driven logistics industry.

\section{References}

Baird, A. J. 1995. Privatization of trust ports in the United Kingdom: Review and analysis of the first sales. Transport Policy, Vol.2, No.2: 135-143.

Baird, A. J. 2002. Privatization trends at the world's top-100 container ports. Maritime Policy \& Management, Vol.29, No.3: 271-284.

Beresford, A. K. C., B. M. Gardner, S.J. Pettit, A. Naniopoulos, and C. F. Wooldridge. 2004. The UNCTAD and WORKPORT models of port development: Evolution or revolution? Maritime Policy \& Management, Vol.31, No.2: 93-107.

Bichou, K., and R. Gray. 2004. A logistics and supply chain management approach to port performance measurement. Maritime Policy \& Management, Vol.31, No.1: 47-67. 
Bird, J. H. 1963. The major seaports of the United Kingdom. London: Hutchison.

Bird, J. H. 1971. Seaports and seaport terminals. London, London: Hutchison.

Bird, J. and G. Bland 1988. Freight forwarders speak. Maritime Policy and Management, Vol. 15, No.1: 35-55.

Brandenburger, A., and B. Nalebuff. 1966. Co-opetition. NY: A Currency Book.

Chan, Y. 2005. A statistical study of intrastate vs. interstate regulatory reforms. Journal of Transport Geography, Vol. 13: 165-171.

Chang, S. E. 2000. Disasters and transport systems: Loss, recovery and competition at the Port of Kobe after the 1995 earthquake. Journal of Transport Geography, Vol. 8, No.1: 53-65.

Chang, Y-T, S. Lee, and S. Lie. 2002. Factors affecting liners' port selection by trade route Seoul. In-House Report. Korea Maritime Institute.

Charles River Associates (Asia Pacific) Ltd. 2002. Port companies and market power - A quantitative analysis. Final Report.

Christidis, P. 2001. Port development and competition issues. IPTS Report. 54.

Cullinane, K., D.-W. Song, and R. Gray. 2002. A stochastic frontier model of the efficiency of major container terminals in Asia: Assessing the influence of administrative and ownership structures. Transport Research Part A, Vol.36: 743-762.

Cullinane, K., D.-W. Song, and T. Wang. 2005. The application of mathematical programming approaches to estimating container port production efficiency. Journal of Productivity Analysis, Vol.24: 73-92.

Defilippi, E. (2004). Intra-port competition, regulatory challenges and the concession of Callao port. Maritime Economics \& Logistics, Vol.6: 279-311.

De Langen, P. 2004. Policy perspective: Governance in seaport clusters. Maritime Economics and Logistics, Vol.6: 141-156.

Dillion, W., and M. Goldstein. 1984. Multivariate analysis: Methods and applications. NY: John Wiley \& Sons.

Estache, A., M. Gonzalez, and L. Trujillo. 2002. Efficiency gains from port reform and the potential for yardstick competition: Lessons from Mexico. World Development, Vol.30, No.4: 545-560.

Everett, S. 2003. Corporatization: A legislative framework for port inefficiencies. Maritime Policy and Management, Vol.30, No.3: 211-219.

Fung, K. F. 2001. Competition between the port of Hong Kong and Singapore: A structural vector error correction model to forecast the demand for container handling services. Maritime Policy and Management, Vol.28, No.1: 3-22.

Gibson, B., H. Sink, and R. Mundy. 1993. Shipper-carrier relationship and carrier selection criteria. Logistics and Transportation Review, Vol. 29, No.4: 371-382.

Goss, R. 1990a. Economic policy and seaports: 1. The economic functions of seaports. Maritime Policy and Management, Vol. 17, No.3: 207-220.

Goss, R. 1990b. Economic policy and seaports: 2. The diversity of port policies. Maritime Policy and Management, Vol.17, No. 3: 221-234.

Goss, R. 1990c. Economic policies and seaports: 3. Are port authorities necessary? Maritime 
Policy and Management, Vol.17, No.4: 257-271.

Hall, P. V. 2003. Regional institutional convergence? Reflections from the Baltimore Waterfront. Economic Geography, Vol.79, No.4: 347-363.

Hayuth, Y. 1987. Intermodality: Concept and practice. London: Lloyds of London Press.

Haralambides, H. 2002. Competition, excess capacity, and the pricing of port infrastructure. International Journal of Maritime Economics, Vol.4: 323-347.

Heaver, T. et al. 2001. Co-operation and competition in international container transport: Strategies for ports. Maritime Policy and Management, Vol.28, No.3: 293-305.

Heaver, T., H. Meersman, and E. van der Voorde. 2000. Do mergers and alliances influences European shipping and port competition? Maritime Policy and Management, Vol.27, No.4: 363-373.

Hoyle, B., and J. Charlier. 1995. Inter-port competition in developing countries: An East African case study. Journal of Transport Geography, Vol.3, No.2: 87-103.

Ircha, M. C. 2001. Port strategic planning: Canadian port reform. Maritime Policy and Management, Vol.28, No.2: 125-140.

Kim, Y., G. Hong, and C. Shin. 2004. An empirical study on port selection criteria. Journal of Korean Navigation and Port Research, Vol. 28, No. 6: 525-530.

Konings, R., and M. Ludema. 2000. The competitiveness of the river-sea transport system: Market perspectives on the United Kingdom-Germany corridor. Journal of Transport Geography. Volume 8, No. 3: 221-228.

Lago, A., M. Malchow, and A. Kanafani. 2001. An analysis of carriers' schedules and the impact on port selection. Proceedings of IAME Annual Conference 2001, Hong Kong: 123-137.

Lu, C. 2000. Logistics services in Taiwanese maritime firms. Transportation Research Part E, Vol.36: 79-96.

Mak, J., and B. K. Tai. 2001. Comment - Port development within the framework of Malaysia's transport policy: Some considerations. Maritime Policy \& Management, Vol.28, No.2: 199-206.

Malchow, M., and A. Kanafani. 2001. A disaggregate analysis of factors influencing port selection. Maritime Policy and Management, Vol.28, No.3: 265-277.

McCalla, R. J. 1999. Global change, local pain: Intermodal seaport terminals and their service areas. Journal of Transport Geography, Vol.7, No.4: 247-254.

Murphy, P., and J. Daley. 1994. A comparative analysis of port selection factors. Transportation Journal, Vol.34, No.1: 15-21.

Murphy, P. R., J. M. Daley, and D.R. Dalenberg. 1992. Port selection criteria: An application of a transportation research framework. Logistics and Transportation Review, Vol.28, No.3: 237-255.

Nir, A.-S., et al. 2003. Port choice behavior - From the perspective of the shipper. Maritime Policy and Management, Vol.30, No.2: 165-173.

Notteboom, T. E., and J.-P. Rodrigue 2005. Port regionalization: Towards a new phase in port development. Maritime Policy and Management, Vol.32, No.3: 297-313.

Oum, T.-H. 1989. Alternative demand models and their elasticity estimates. Journal of 
Transport Economics and Policy, May: 163-186.

Pallis, A. A., and G. K. Vaggelas 2005. Port competitiveness and the EU 'port services' directive: The case of Greek ports. Maritime Economics and Logistics, Vol.7: 116-140.

Petez-Labajos, C., and B. Blanco. 2004. Competitive policies for commercial sea ports in the EU. Marine Policy, Vol.28: 553-556.

Prince, T. 1999. Earnest port search. Journal of Commerce, Vol. 11.

Rimmer, P. J. 1967. The search for spatial regularities among Australian seaports. Geografiska Annaler, Vol. 49, Ser. B: 42-54.

Robinson, R. 2002. Ports as elements in value-driven chain systems: The new paradigm. Maritime Policy and Management, Vol.29, No.3: 241-255.

Slack, B. 1985. Containerization, interport competition and port selection. Maritime Policy and Management, Vol. 12, No. 4: 293-303.

Slack, B. and A. Frémont. 2005. Transformation of port terminal operations: From the local to the global. Transport Reviews, Vol. 25, No.1: 117-130.

Song, D-W., K. Cullinane, and M. Roe. 2001. Productive efficiency of container terminals. England: Ashgate.

Song, D.-W. 2002. Regional container port competition and co-operation: The case of Hong Kong and South China. Journal of Transport Geography, Vol.10, No.2: 99-110.

Song, D.-W. 2003. Port co-opetition in concept and practice. Maritime Policy and Management, Vol.30, No.1: 29-44.

Taaffe, E. J., R.L. Morrill, and P.R, Gould, P. R.1963. Transport expansion in underdeveloped countries: A comparative analysis. Geographical Review, 53: 503-529.

Terada, H. 2002. An analysis of the overcapacity problem under the decentralized management system of container ports in Japan. Maritime Policy \& Management, Vol.29, No.1: 3-15.

Thai, V. V., and D. Grewal. 2005. An analysis of the efficiency and competitiveness of Vietnamese port system. Asia Pacific Journal of Marketing and Logistics, Vol.17, No.1: 3-31.

Tongzon, J. 1995. Determinants of port performance and efficiency. Transportation Research Part A, Vol.29A, No.3: 245-252.

Tongzon, J. 2001. Efficiency measurement of selected Australian and other international ports using data envelopment analysis. Transportation Research Part A, Vol.35: 107-122.

Tongzon, J. 2002. Port choice determinants in a competitive environment. IAME, CIT.

Tongzon, J., and W. Heng. 2005. Port privatization, efficiency and competitiveness: Some empirical evidence from container ports (terminals). Transportation Research Part A: Policy and Practice, Vol. 39: 405-424.

Van Klink, H. A., and G. C. Van Den Berg. 1998. Gateways and intermodalism. Journal of Transport Geography, Vol.6, No.1: 1-9.

Veldman, S. J., and E. H. Buckmann. 2003. A model on container port competition: An application for the West European container hub-ports. Maritime Economics and Logistics, Vol.5: 3-22.

Wang, J. J. 1998. A container load center with a developing hinterland: A case study of Hong 
Kong. Journal of Transport Geography, Vol.6, No.3: 187-201.

Wang, J. J., and B. Slack. 2000. The evolution of a regional container port system: The Pearl River Delta. Journal of Transport Geography, Vol.8, No.4: 263-275.

Wang, J. J., and B. Slack. 2004. Regional governance of port development in China: A case study of Shanghai International Shipping Center. Maritime Policy and Management, Vol.31, No.4: 357-373.

Wang, J.J., A. K-Y. Ng, and Daniel Oliver. 2004. Port governance in China: A review of policies in an era of internationalizing port management practices. Transport Policy, Vol.11: 237-250.

Wang, T., K. Cullinane, and D.W. Song. 2005. Container port production and economic efficiency. London: Palgrave MacMillan.

Winkelmans, W. 2003. Port competitiveness and port competition: Two of a kind? ITMMA, University of Antwerp.

Yap, W. Y., and J. S. L. Lam. 2006. Competition dynamics between container ports in East Asia. Transport Research Part A: Policy and Practice, Vol.40: 35-51.

Yeo, K., H. Lee, and S. Oh. 2004. Extraction of port selection factors for increasing shippers' attraction of small and medium ports. (written in Korean). Journal of Shipping and Logistics, Vol. 43, No. 4: 33-53.

Zan, Y. 1999. Analysis of container port policy by the reaction of an equilibrium shipping market. Maritime Policy and Management, Vol. 26, No.4: 369-381. 